\title{
GRASS WEEDS INTERFERING WITH EUCALYPT: EFFECTS OF THE Distance of Coexistence on the Initial Plant Growth ${ }^{1}$
}

\author{
Plantas Daninhas Gramíneas Interferindo no Eucalipto: Efeitos da Distância da Convivência no \\ Crescimento Inicial das Plantas
}

GRAAT, Y. ${ }^{2}$, ROSA, J.O. ${ }^{2}$, NEPOMUCENO, M.P. ${ }^{2}$, CARVALHO, L.B. ${ }^{3}$, and ALVES, P.L.C.A. ${ }^{2}$

\begin{abstract}
Two experiments were carried out to evaluate the initial plant growth of Eucalyptus urograndis growing in coexistence with Urochloa decumbens and U. ruziziensis. In 100-L box, one plant of $U$. decumbens or $U$. ruziziensis grew in coexistence with one plant of $E$. urograndis clones $\mathrm{C} 219 \mathrm{H}$ or $\mathrm{H} 15$, respectively, in the distances of $0,5,10,15,20,25,30,35$, and $40 \mathrm{~cm}$ from the crop. After 30, 60, 90 (both clones), and 150 days (just for $\mathrm{H} 15$ ), growth characteristics were evaluated. Plants of both clones, growing in weed-free situations, showed a better growth and development than plants that grew in weedy situations, independently of the distance, having the highest plant height, stem diameter, dry mass of stem, and dry mass of leaves. As the same way, the number of branches, number of leaves, and leaf area of the clone $\mathrm{C} 219 \mathrm{H}$ were similarly affected. Urochloa ruziziensis reduced the dry mass accumulation of stem and leaves by the rate of 0.06 and $0.32 \mathrm{~g}$ per plant, respectively, per each centimeter growing nearest to the crop, while $U$. decumbens reduced by 0.03 and $0.14 \mathrm{~g}$ per plant. The interference of $U$. decumbens and $U$. ruziziensis with E. urograndis is more intense when weedy plants grow in short distances from the crop.
\end{abstract}

Keywords: Eucalyptus urograndis, Urochloa decumbens, Urochloa ruziziensis, weed competition.

\begin{abstract}
RESUMO - Dois experimentos foram realizados para avaliar o crescimento inicial das plantas de Eucalyptus urograndis crescendo em convivência com Urochloa decumbens e U. ruziziensis. Em vasos de concreto de $100 \mathrm{~L}$, uma planta de $\boldsymbol{U}$. decumbens ou $\boldsymbol{U}$. ruziziensis cresceu em coexistência com uma planta de $\boldsymbol{E}$. urograndis, dos clones $\mathrm{C} 219 \mathrm{H}$ ou $\mathrm{H} 15$, respectivamente, nas distâncias de $0,5,10,15,20,25,30,35$ e 40 centímetros a partir da planta de eucalipto. Depois de 30, 60, 90 (para ambos os clones) e 150 dias (apenas para H15), caracteristicas de crescimento foram avaliadas. As plantas de ambos os clones, crescendo em situações livres de plantas daninhas, apresentaram melhor crescimento e desenvolvimento do que as plantas que cresceram em situações de convivência, independentemente da distância, tendo a maior altura da planta, diâmetro do caule, massa seca de caule e massa seca de folhas. De forma similar, foram afetados o número de ramos, o número de folhas e a área foliar do clone $\mathrm{C} 219 \mathrm{H}$. Urochloa ruziziensis reduziu o acúmulo de massa seca de caule e folhas na taxa de 0,06 e 0,32 g por planta, respectivamente, por cada centímetro de crescimento mais próxima à cultura, enquanto $\boldsymbol{U}$. decumbens reduziu de 0,03 e $0,14 \mathrm{~g}$ por planta. A interferência da $\boldsymbol{U}$. decumbens $e \boldsymbol{U}$. ruziziensis com $\boldsymbol{E}$. urograndis é mais intensa quando as plantas daninhas crescem em curtas distâncias da cultura.
\end{abstract}

Palavras-chave: Eucalyptus urograndis, Urochloa decumbens, Urochloa ruziziensis, matocompetição.

1 Recebido para publicação em 5.12.2014e aprovado em 24.2.2015.

2 Universidade Estadual Paulista UNESP - FCAV, Jaboticabal-SP, Brasil, <plalves@fcav.unesp.br>; ${ }^{3}$ Universidade do Estado de Santa Catarina, UDESC, Lages-SC, Brasil. 


\section{INTRODUCTION}

Eucalypt (Eucalyptus spp.) plantations are expanding very fast, and the average production and yield have been increasing in the past years, so that crop is emerging as the main species for wood and cellulose production in Brazil, including for the international trade (ABRAF, 2013). According to this association, about 5.1 million hectares were grown in 2012 which produce 13.9 million tonnes of cellulose and 5.8 million tonnes of charcoal, allowing Brazil to attain the third position of the main cellulose producers worldwide, exporting 4.7 billion dollars and employing more than 1.5 million people. Among many species and clones, $95 \%$ of Brazilian eucalypt forests have grown with Eucalyptus urograndis (Eucalyptys grandis x Eucalyptus urophylla) clones (Paludzyszyn Filho, 2010), an eucalypt hybrid developed in Brazil. However, the presence of weeds can be detrimental to the establishment and maintenance of eucalyptus forests (Silva et al., 2012).

The weed interference is one of the main factors that can reduce growth of eucalypt crop, compromising its development and productivity (Pereira et al., 2010). Weeds compete with eucalypt for water, nutrients, light, and other factors, reducing its quantitative and qualitative characteristics (Souza et al., 2010). The competition occurs when the supply of one or more factors essential to plant growth and development falls below the combined demands of both plants (Anderson, 1996). Weed interference with forest species can be divided into direct (e.g., competition and allelopathy) and indirect (e.g., host of pests and diseases, or even and interfering with productive activities, as manuring, irrigations, and harvest) (Souza et al., 2003). Thus, knowing the potential impact of weeds on plant growth is important to understand when weeds must be controlled before the interference is established.

A large number of weeds infests eucalypt forests, including monocotyledonous and eudicotyledonouss. However, many eucalypt forests were established on old degraded pastures of Urochloa spp. (Syn. Brachiaria spp.), so that species of that genus are considered the main weeds infesting eucalypt forests in
Brazil. Toledo et al. (2001) reported the importance of Urochloa decumbens as a weed in eucalypt forests, reducing the stem diameter, plant height, leaf number, and leaf area by $27.8 \%, 18.5 \%, 70.6 \%$, and $63.3 \%$, respectively; in addition, stem, branch, and leaf dry mass were reduced by $55.2 \%, 77.3 \%$, and $55.3 \%$, respectively. Urochloa ruziziensis another species cultivated as a pasture in the past where and that on which young eucalypt forests have been established in the last years, on which research information about weed interference is scarce.

Abiotic and biotic factors can affect the degree of weed interference in addition to the weed species coexistence with the interesting crop (Souza et al., 2003; Garau et al., 2009; Pereira et al., 2013). Weed spatial distribution in the field is one of the main factors affecting the degree of weed interference (Norris et al., 2001a,b). Thus, considering that weed control in perennial crops is commonly performed by keeping a strip of the planting line free of weeds, the distance between the weedy plant and the interesting plant becomes fundamental to determinate the interference degree under this situation. Silva et al. (2012) studied the influence of weed control strips on eucalypt growth and observed that weeds growing close $75 \mathrm{~cm}$ to eucalypt plants reduced significantly crop growth. Silva et al. (2010) and Barroso et al. (2012) also reported plant growth and yield reductions of tomato and bean crops when weeds had grown close to the planting line.

We hypothesized that plants of $U$. decumbens and $U$. ruziziensis growing in different distances of $E$. urograndis plants do not affect similarly the crop initial growth. The objective of this research was to investigate the E. urograndis plant growth reduction under coexistence with $U$. decumbens and $U$. ruziziensis plants that grew at in difference distances from the crop plants.

\section{MATERIAL AND METHODS}

Two experiments were carried out in $100 \mathrm{~L}$ concrete cement box $(0.62 \mathrm{~m}, 0.62 \mathrm{~m}$, and $0.26 \mathrm{~m}$ ) maintained under natural environmental conditions at $21^{\circ} 15^{\prime} 22^{\prime \prime} \mathrm{S}$ and $48^{\circ} 18^{\prime} 58^{\prime}$ "WGr., altitude of $592 \mathrm{~m}$, in a Cwa 
climate (subtropical mesothermic with wet summers and dry winters) with an average temperature, rainfall, and relative humidity of $22{ }^{\circ} \mathrm{C}, 1,285 \mathrm{~mm}$, and $70.6 \%$, respectively.

\section{Experiment 1: Interference of $U$. decumbens with eucalypt}

The first experiment was carried out from October to December, 2010. The substrate used to fill the boxes derived from an eutrophic Red Lotosol clay textured, corresponding to a Rhodic Ferralsol (FAO, 2014) or a Rhodic Eutrudox (USDA, 2014), with the following characteristics: $\mathrm{pH}=6.0\left(\mathrm{CaCl}_{2}\right)$; $\mathrm{MO}=21 \mathrm{~g} \mathrm{dm}^{-3} ; \mathrm{P}$ (resin) $=66 \mathrm{mg} \mathrm{dm}^{-3} ; 4.3,49$, $28,18,81.3$, and $99.3 \mathrm{mmol}_{\mathrm{c}} \mathrm{dm}^{-3}$ of $\mathrm{K}, \mathrm{Ca}, \mathrm{Mg}$, $\mathrm{H}+\mathrm{Al}, \mathrm{SB}$, and $\mathrm{T}$, respectively; $\mathrm{V}=82 \%$; clay $=54.3 \%$, lime $=19.7 \%$, and sand $=26 \%$. Limestone was not applied, but NPK was supplied at $200 \mathrm{~kg} \mathrm{ha}^{-1}$ (4-14-8) in the crop planting time.

We used E. urograndis $\mathrm{C} 219 \mathrm{H}$ clonal seedlings and $U$. decumbens seedlings preformed in trays filled with organic substrate (Plantmax $\mathrm{HT}^{\circledR}$, Brazil), using seeds collected under field conditions. Eucalypt seedlings were planted into concrete boxes when they were 90 days old and similar $U$. decumbens seedlings were transplanted into concrete boxes when they showed 4-5 well-developed leaves (similarly to $\mathrm{BBCH} 14-15$ ).

Treatments consisted of keeping one eucalypt plant in coexistence with one weedy plant, within each box, growing under distinct distances of each other: $0,5,10,15,20,25$, 30,35 , and $40 \mathrm{~cm}$. A weed-free check (control) was also kept with one eucalypt plant growing in coexistence with no weedy plant. The experimental design with 10 treatments and four replicates was arranged in a completely randomized design.

Evaluations were performed at 30,60 , and 90 days after crop planting (DAP). The distance from the plant basis close to the soil surface until the top of the stem (plant height) and the width of the stem at $3 \mathrm{~cm}$ above the soil surface (stem diameter) were measured at each time of evaluation by using a graduated stick $(\mathrm{cm})$ and a digital paquimeter $(\mathrm{mm})$, respectively. In addition, the number of leaves and branches were counted while the plant leaf area was measured by using a electronic leaf area meter $\left(\mathrm{dm}^{2}\right)$ (LiCor, LI3000A, USA) after leaves had just been collected at 90 DAP; eucalypt dry mass of stem and leaves were also determinate, as well as the above ground dry mass of the weedy plant, at 90 DAP, after being collected and dried in a forced air convection oven at $70{ }^{\circ} \mathrm{C}$ during 96 hours, by using a semi-analytical balance (0.01 g).

\section{Experiment 2: Interference of $U$. ruziziensis with eucalypt}

The second experiment was carried out from June to November, 2010. The substrate used to fill the concrete boxes derived from the same soil of the Experiment 1, however showing the following characteristics: $\mathrm{pH}=5.3$ $\left(\mathrm{CaCl}_{2}\right) ; \mathrm{MO}=25 \mathrm{~g} \mathrm{dm}^{-3} ; \mathrm{P}$ (resin) $=53 \mathrm{mg} \mathrm{dm}^{-3}$; $4.7,47,17,38,68.4$, and $106.7 \mathrm{mmol}_{\mathrm{c}} \mathrm{dm}^{-3}$ of $\mathrm{K}, \mathrm{Ca}, \mathrm{Mg}, \mathrm{H}+\mathrm{Al}, \mathrm{SB}$, and $\mathrm{T}$, respectively; $\mathrm{V}=65 \%$; clay $=54.8 \%$, lime $=19.4 \%$, and sand $=25,8 \%$. Limestone $($ PRNT $=70 \%)$ was applied at $2 \mathrm{t} \mathrm{ha}^{-1}$ at 60 days before crop planting and NPK was supplied at $200 \mathrm{~kg} \mathrm{ha}^{-1}$ (4-14-8) in the crop planting time.

It was used E. urograndis H15 clonal seedlings and $U$. ruziziensis seedlings preformed in trays filled with organic substrate (Plantmax $\mathrm{HT}^{\circledR}$, Brazil), grown from seeds collected under field conditions. Eucalypt seedlings were planted into concrete boxes when they were 135 days old and $U$. ruziziensis seedlings were transplanted into the same boxes at 4-5 well-developed leaves (similarly to $\mathrm{BBCH}$ 14-15).

Treatments, experimental design, and number of replicates were similar to the first experiment. Similar evaluations to the first experiment were performed at 30,60,90, and 150 DAP, excepting number of leaves and branches. The eucalypt plant height and stem diameter were counted at each time of evaluation while the dry mass of stem and leaves of eucalypt plants and the aboveground dry mass of the weedy plant were determined at 150 DAP.

\section{Statistical analysis}

Dry mass data of the weedy plants were submitted to a linear regression analysis by 
using the software SigmaPlot version 10.0, for both experiments.

Plant height and stem diameter (for both experiments) and the number of leaves and branches (for the first experiment) were submitted to a previous univariate ANOVA (F test), according to a factorial scheme of 10x3 or $10 \times 4$ (10 treatments $\times 3$ or 4 times of evaluation in a split plot in time design), for the first experiment and the second experiment, respectively; the dry mass of stem and leaves data were submitted to a previous univariate ANOVA (F test), for both experiments. Moreover, means were compared to the weedfree check by Dunnett test at $5 \%$ of probability by using the software Statistica version 8.0, for both experiments. In addition, excluding the check treatment, data were also submitted to a linear regression analysis by using the software Sigma Plot version 10.0, for both experiments.

\section{RESULTS AND DISCUSSION}

\section{Weedy species results}

Urochloa decumbens and U. ruziziensis showed different behavior growing in coexistence with eucalypt plants in accordance to the distance in that the weedy species grew in relation to the interesting

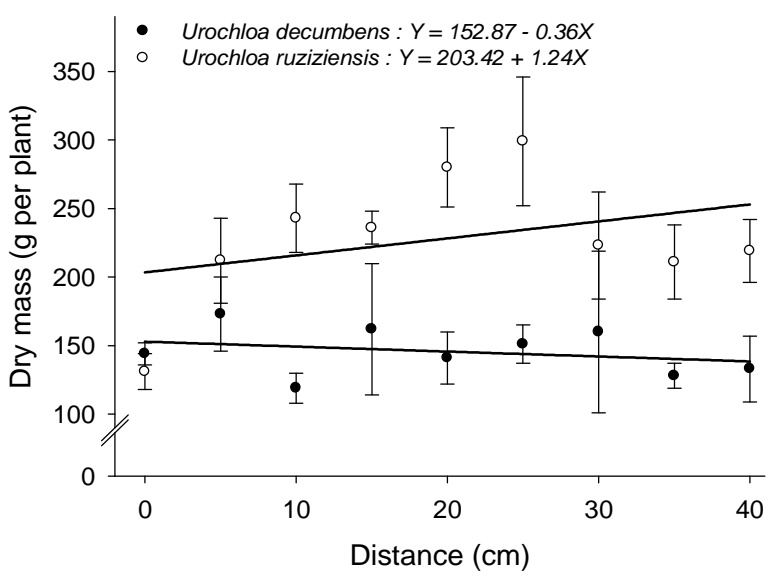

Figure 1 - Aboveground dry mass of Urochloa decumbens (90 days after planting $-\mathrm{R}^{2}=0.43$ ) and Urochloa ruziziensis (150 days after planting $-\mathrm{R}^{2}=0.68$ ) growing in coexistence with one plant of Eucalyptus urograndis C219H and H15 clones, respectively, and being maintained within different distances from the eucalypt plant. plant. In general, as the distance increased, the dry mass accumulation of $U$. decumbens decreased (Figure 1). On the other hand, $U$. ruziziensis increased the dry mass accumulation when the distance increased. For each centimeter increased in the distance, $U$. decumbens decreased its dry mass accumulation by $0.36 \mathrm{~g}$ per plant while $U$. ruziziensis increased its dry mass accumulation by $1.24 \mathrm{~g}$ per plant (Figure 1). Besides determination coefficients $\left(R^{2}\right)$ of linear regression were not high $\left(\mathrm{R}^{2}=0.4\right.$ for $U$. decumbens and $\mathrm{R}^{2}=0.7$ for $U$. ruziziensis), we stated that the plant behavior was linear with acceptable $\mathrm{P}$ values $(\mathrm{P}<0.15)$. In addition, non-linear regressions did not improve significantly $\mathrm{R}^{2}$ or $\mathrm{P}$ values and did not represent the biological behavior of plants (e.g. polynomial of the third degree).

\section{Eucalypt clones results}

The interaction between the distance and the time of evaluation was significant for plant height and stem diameter $(\mathrm{P}<0.05)$, in both experiments. In addition, similar observation is valid for the eucalypt clones results, regarding on the regression analysis $\left(\mathrm{R}^{2}\right.$ ranged from 0.5 up to 0.7 , and $\mathrm{P}$ values $<0.12$ ).

In the first experiment (U. decumbens coexisting with E. urograndis clone C219), Dunnett test $(\mathrm{P}<0.05)$ indicated difference between the weed-free check in comparison to all treatments with weed coexistence at 60 and 90 DAP for both plant height (Figure 2A) and stem diameter (Figure $3 \mathrm{~A}$ ). The general average eucalypt plant height was $35.9 \mathrm{~cm}$ at 30 DAP, including the weed-free check. In addition, eucalypt plant height of the weed-free check was 70.5 and $119.2 \mathrm{~cm}$ while the average of the eucalypt weedy treatments (55.3 and $76.8 \mathrm{~cm}$ ) was 15.2 and $42.4 \mathrm{~cm}$ lower than the weed-free check, at 60 and 90 DAP, respectively. Moreover, the general average of the eucalypt stem diameter was $4.0 \mathrm{~mm}$ at 30 DAP, including the plants in the weed-free check. In addition, the stem diameter of the weed-free check eucalypt was 9.8 and $16.3 \mathrm{~mm}$ while the average of the eucalypt weedy treatments $(7.4$ and $10.3 \mathrm{~mm})$ was 2.4 and $6.0 \mathrm{~mm}$ lower than the weed-free check, at 60 and 90 DAP, respectively. 


\section{(A)}

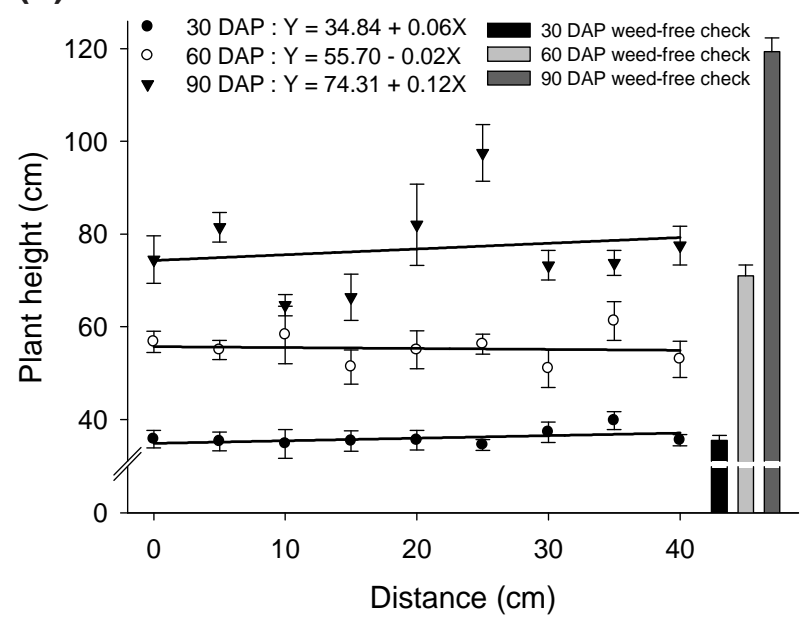

(B)

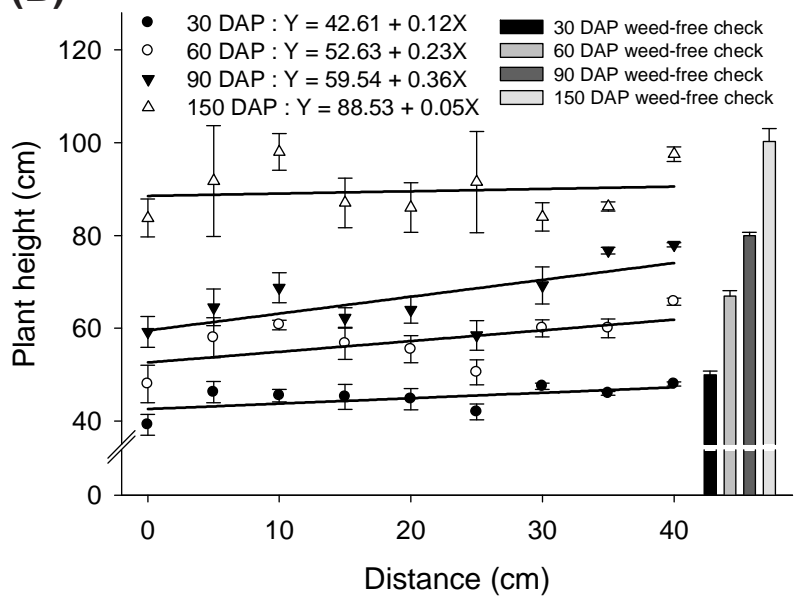

Figure 2 - Plant height of clones of Eucalyptus urograndis C219H (A) and H15 (B), growing in coexistence with Urochloa decumbens (A) and Urochloa ruziziensis (B) and being maintained within different distances from the eucalypt plant. DAP indicates days after planting. $\mathrm{R}^{2}$ ranged from 0.51 up to 0.72 .

In the second experiment ( $U$. ruziziensis coexisting with E. urograndis clone H15), Dunnett test $(\mathrm{P}<0.05)$ indicated difference between the weed-free check in comparison to some treatments with weed coexistence at 30, 60, 90, and 150 DAP for both plant height (Figure 2B) and stem diameter (Figure 3B). The highest plant height was verified in the eucalypt weed-free check, reaching values of $50.0,67.0,80.0$, and $100.3 \mathrm{~cm}$, while the lowest plant height was observed at the distance of $0 \mathrm{~cm}$, with values of 39.3, 48.0, 59.3 , and $83.8 \mathrm{~cm}$, at $30,60,90$, and $150 \mathrm{DAP}$, respectively, representing a reduction of 10.8 ,
$19.0,20.8$, and $16.5 \mathrm{~cm}$. The highest stem diameter was also verified in the eucalypt weed-free check, reaching values of 12.4 , $14.7,019.0$, and $22.7 \mathrm{~mm}$, however the lowest plant height was observed at the distance of $25 \mathrm{~cm}$, being $7.3,10.2,12.8$, and $16.3 \mathrm{~mm}$, at $30,60,90$, and $150 \mathrm{DAP}$, respectively, representing a reduction of $5.1,4.5,6.2$, and $6.4 \mathrm{~mm}$.

In general, as the distance increased, the plant height of both eucalypt clones also increased (Figures 2A and 2B), excepting for $\mathrm{C} 219 \mathrm{H}$ at $60 \mathrm{DAP}$ (Figure 2A). The clone

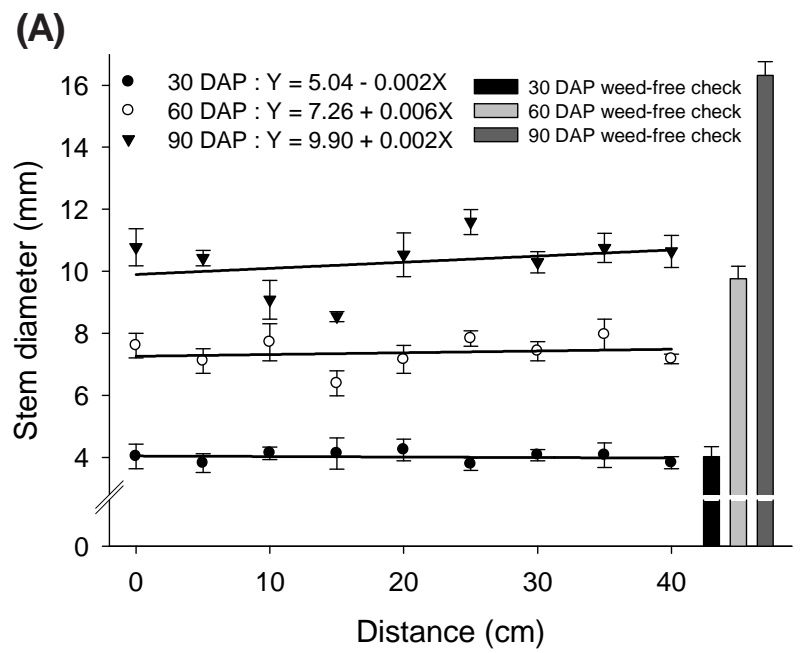

(B)

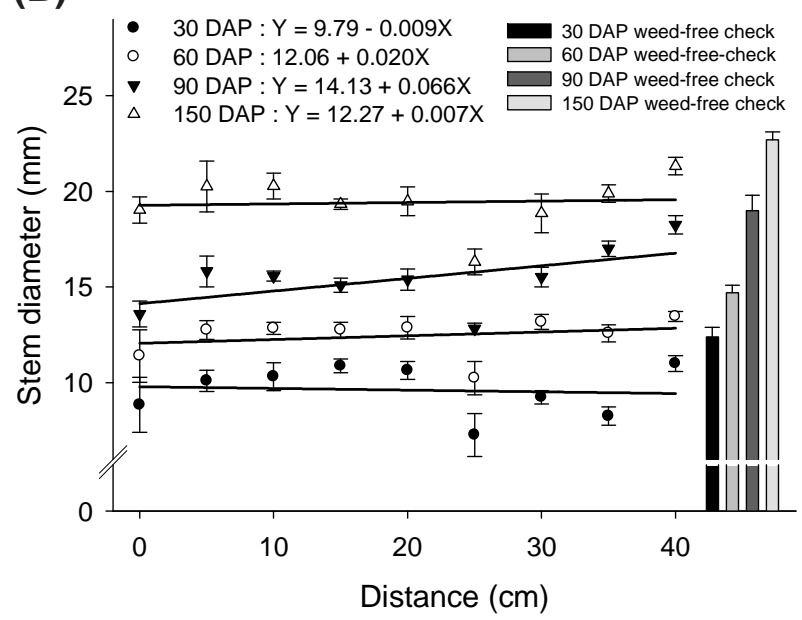

Figure 3 - Stem diameter of clones of Eucalyptus urograndis C219H (A) and H15 (B), growing in coexistence with Urochloa decumbens (A) and Urochloa ruziziensis (B) and being maintained within different distances from the eucalypt plant. DAP indicates days after planting. $\mathrm{R}^{2}$ ranged from 0.55 up to 0.73 . 
$\mathrm{C} 219 \mathrm{H}$ increased the plant height by 0.06 and $0.12 \mathrm{~cm}$ per each centimeter increased in the distance at 30 and 90 DAP, respectively, in spite of decreasing by $0.02 \mathrm{~cm}$ per each centimeter increased in the distance at 60 DAP (Figure 2A). The clone H15 increased the plant height by $0.12,0.23,0.36$, and $0.05 \mathrm{~cm}$ per each centimeter increased in the distance at 30,60, 90, and $150 \mathrm{DAP}$, respectively (Figure 2B). Moreover, in general, as the distance increased, the stem diameter of both eucalypt clones also increased, excepting at 30 DAP for both clones (Figures 3A and $3 \mathrm{~B}$ ). At $30 \mathrm{DAP}$, for each centimeter increased in the distance, the stem diameter reduced by 0.002 and $0.009 \mathrm{~mm}$ for the clones C219H (Figure 3A) and H15 (Figure 3B), respectively. On the other hand, the clone $\mathrm{C} 219 \mathrm{H}$ increased the stem diameter by 0.006 and $0.020 \mathrm{~mm}$ per each centimeter increased in the distance at 60 and 90 DAP (Figure 3A), respectively, while the clone $\mathrm{H} 15$ increased the stem diameter by $0.0020,0.066$, and $0.007 \mathrm{~mm}$ per each centimeter increased in the distance at 60,90 , and 150 DAP (Figure 3B), respectively.

Dunnett test $(\mathrm{P}<0.05)$ indicated difference between the weed-free check in comparison to all treatments with weed coexistence for number of branches, number of leaves, and leaf area (in the first experiment) (Figure 4). The weed-free check eucalypt plants showed 26 branches, 511 leaves, and leaf area of $76.72 \mathrm{dm}^{2}$ while the average values of the eucalypt weedy treatments (17 branches, 224 leaves, and leaf area of $27.80 \mathrm{dm}^{2}$ ) were 9 branches, 287 leaves, and leaf area of $48.92 \mathrm{dm}^{2}$ lower than the weed-free check, at 90 DAP. In general, as the distance increased, number of branches, number of leaves, and leaf area also increased (Figures 4A, 4B, and $4 \mathrm{C}$ ). For each centimeter increased in the distance, the number of branches, number of leaves, and leaf area increased by 0.019 units (52.6 $\mathrm{cm}$ to increase $1 \mathrm{branch}), 0.20$ units (5 $\mathrm{cm}$ to increase 1 leaf), and $0.027 \mathrm{dm}^{2}$, respectively.

In addition, Dunnett test $(\mathrm{P}<0.05)$ indicated difference between the weed-free check in comparison to all treatments with weed coexistence for dry mass of stem and dry mass of leaves, in both first and second

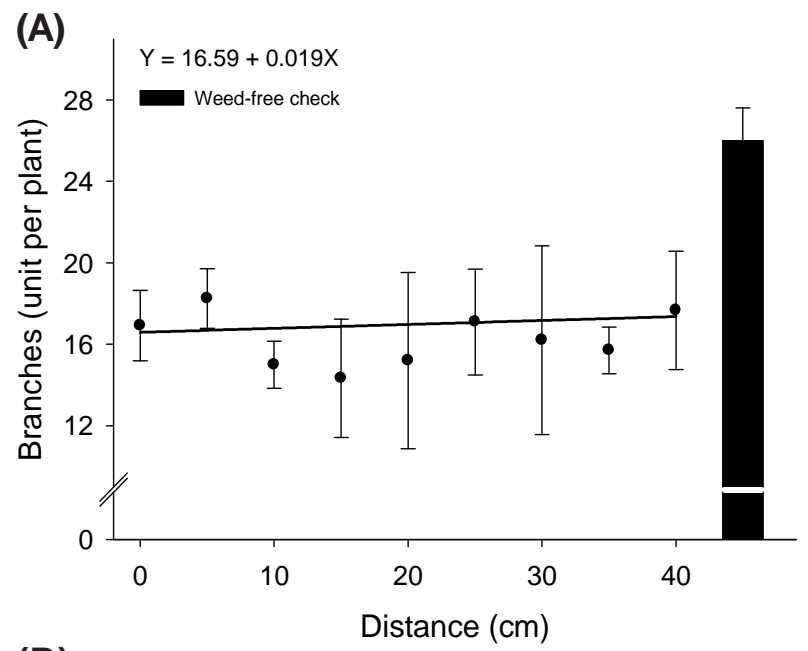

(B)
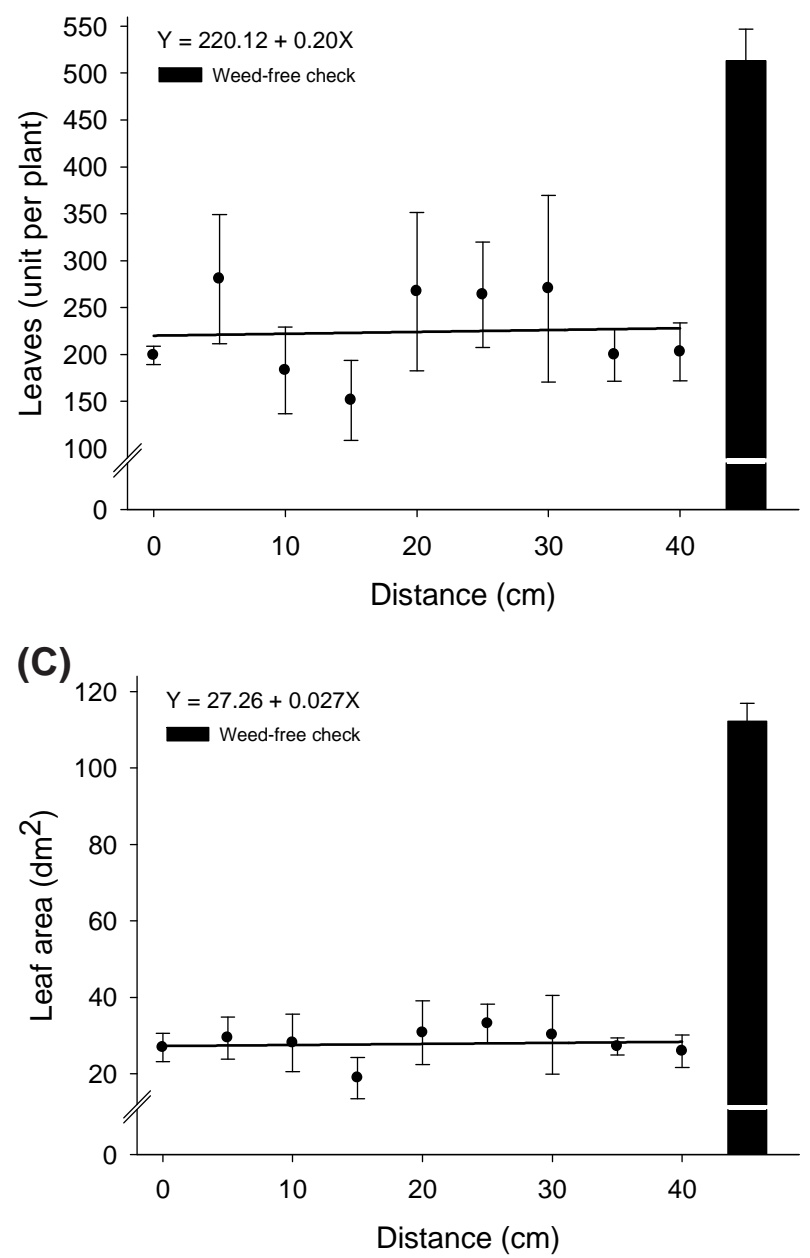

Figure 4 - Number of branches $\left(\mathrm{A}-\mathrm{R}^{2}=0.62\right)$, number of leaves $\left(B-R^{2}=0.54\right)$, and leaf area $\left(C-R^{2}=0.66\right)$ of Eucalyptus urograndis clone $\mathrm{C} 219 \mathrm{H}$, growing in coexistence with Urochloa decumbens at 90 days after planting. The weedy species was maintained within different distances from the eucalypt plant. 
experiments (Figure 5). In general, as the distance increased, the dry mass of stem and leaves also increased, in both experiments (Figures 5A and 5B). In the first experiment, for each centimeter increased in the distance, between the clone $\mathrm{C} 219 \mathrm{H}$ and $U$. decumbens, the dry mass of stem and leaves increased by 0.03 and $0.14 \mathrm{~g}$ per plant, respectively. In the second experiment, for each centimeter increased in the distance, between the clone $\mathrm{H} 15$ and $U$. ruziziensis, the dry mass of stem and leaves increased by 0.06 and $0.32 \mathrm{~g}$ per plant, respectively.

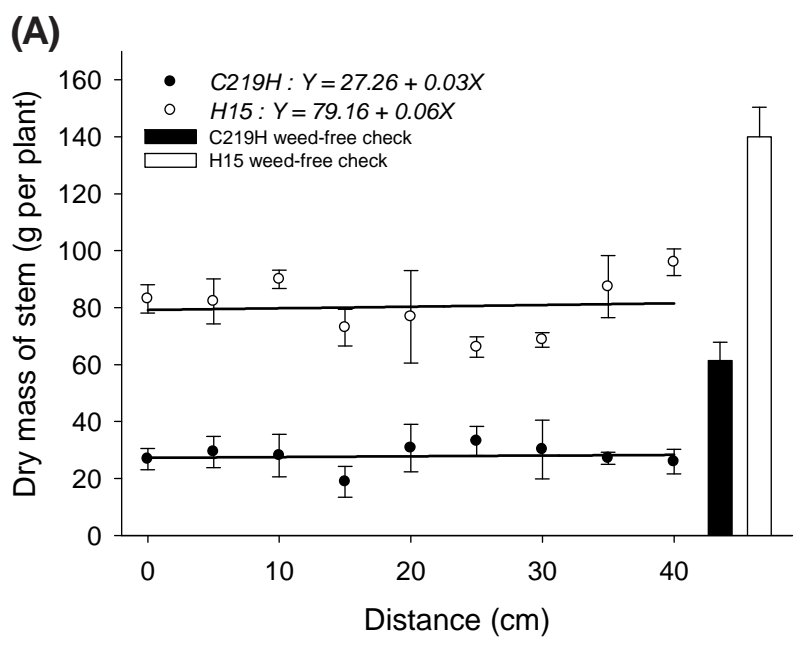

(B)

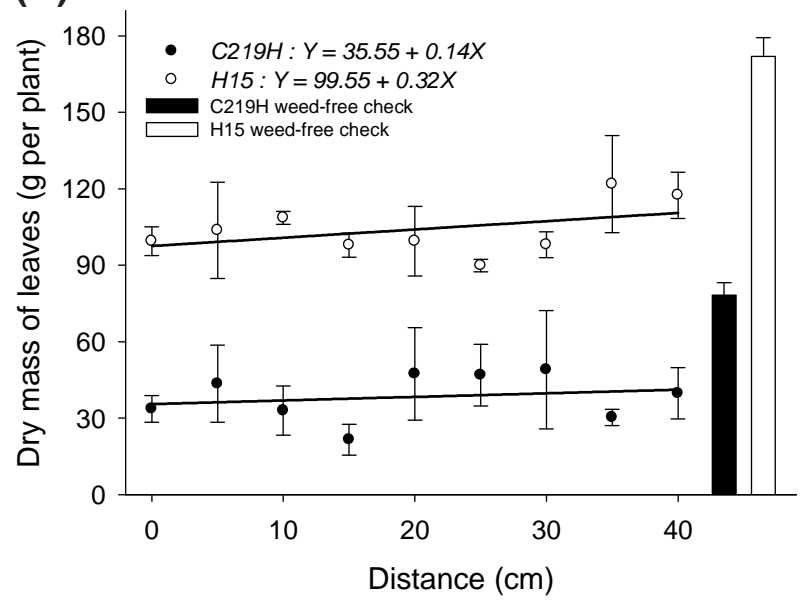

Figure 5 - Dry mass of stem and leaves of clones of Eucalyptus urograndis $\mathrm{C} 219 \mathrm{H}$, growing in coexistence with Urochloa decumbens, and E. urograndis H15, growing with Urochloa ruziziensis, at 90 and 150 days after planting, respectively for each crop. The weedy species was maintained within different distances from the eucalypt plant. $\mathrm{R}^{2}$ ranged from 0.49 up to 0.67 .

\section{General discussion}

The results of weed dry mass accumulation indicate that $U$. decumbens grew better in short distances while U.ruziziensis grew better in long distances from the E. urograndis plants. Marcolini et al. (2009) also observed a better plant growth of $U$. decumbens growing close to coffee plants. However, Barroso et al. (2012) verified that longer distances of coexistence with the bean crop provided the greatest dry mass accumulation by Amaranthus viridis plants and, as a consequence, the lowest productivity of crop. We have expecting that both weeds would grow better in longer distances where they could explore greater amounts of environmental resources, mainly light. However, the eucalypt clone growth behavior could have influences on the weedcrop interaction (Cruz et al., 2010; Pereira et al., 2013), so that the plant architecture and the initial plant growth rate can be different between both clones. Although the plant growth behavior was not evaluated, we can emphasize that the clones $\mathrm{C} 219 \mathrm{H}$ and $\mathrm{H} 15$ showed the average plant height of 77 and $67 \mathrm{~cm}$, respectively, so that difference could influence on the weed growth and partially explain differences between weed growth behavior.

Plants of both clones, $\mathrm{C} 219 \mathrm{H}$ and H15, growing in weed-free situations showed a better growth and development than plants that grew in weedy situations after 30 DAP, independently of the distance, having the highest plant height, stem diameter, dry mass of stem, and dry mass of leaves. The number of branches, number of leaves, and leaf area of the clone $\mathrm{C} 219 \mathrm{H}$ showed also the same behavior. Plant height and stem diameter reduction are commonly reported and occur initially in the first year after eucalyptus plantation (Pitelli \& Marchi, 1988). Evaluating eucalyptus plants in early growth stages coexisting with Panicum maximum and $U$. decumbens plants, Toledo et al. (1999) and Dinardo et al. (2003) observed dry mass reduction of eucalyptus plants. Similar results were also observed by Marcolini et al. (2009), Silva et al. (2010), and Barroso et al. (2012) for coffee, tomato, and bean, respectively, evidencing the impact of weed interference on plant growth. The results allow us to affirm 
that just one plant of $U$. decumbens and $U$. ruziziensis growing in a distance up to $40 \mathrm{~cm}$ from the crop reduced significantly the E. urograndis growth and development. In addition, we can emphasize that $U$. ruriziensis showed an increasing pattern while $U$. decumbens presented a decreasing pattern for dry mass accumulation, suggesting that $U$. ruziziensis was more competitive than $U$. decumbens with $E$. urograndis plants.

The effects of weed-crop interaction can be better comprehended by analyzing the plant dry mass accumulation. In general, as the weedy distance increased, the dry mass of stem and the dry mass of leaves of both clones $\mathrm{C} 219 \mathrm{H}$ and $\mathrm{H} 15$ also increased, indicating that the weed interference with eucalypt plants was higher in short than long distances. The increasing rate of dry mass accumulation was greater in leaves than stem. In addition, that increasing rate was different according to the weed species. Urochloa ruziziensis could reduce dry mass accumulation of stem and leaves by the rate of 0.06 and $0.32 \mathrm{~g}$ per plant, respectively, per each centimeter growing nearest to the crop, while $U$. decumbens could reduce by 0.03 and $0.14 \mathrm{~g}$ per plant. Strong reduction of eucalyptus dry mass due to the interference of $U$. decumbens and $U$. ruziziensis was also observed by Pereira et al. (2013). The great influence of the presence of grasses in the reductions in height and diameter can be explained by the fact that the grasses roots grow very fast, exploring the soil moisture and nutrients better. Furthermore, their high aggressiveness allows a quickly colonization of the area (Toledo et al., 1996).

Studying other Eucalyptus spp., the presence of weeds were a serious threat to the seedlings development of Eucalyptus globules (Garau et al., 2009), Eucalyptus urophylla (Toledo et al., 2000), and Eucalyptus grandis (Souza et al., 2010). On the other hand, Brendolan et al. (2000) evaluated eucalyptus inter and intraspecific competition and found no effects on height, number of leaves and branches, analyzing a period of 60 days of coexistence with weeds. In this case, the lack of competition is probably due to the shot period studied, whereas other authors reported that the period of weed interference in eucalyptus begins at 30 days after plantation. The period of coexistence with the weeds was only 30 days, and the weeds emerged in the area, exerting reduced competitive pressure on eucalyptus plants (Pereira et al., 2013). It evidences that the duration of the coexistence with weeds determines the potential of weed interference on crops as well as all the factors cited above, including the distance within that weeds grow in coexistence with the interesting plants.

Taken together, the results allow us to conclude that: (i) plants of $U$. decumbens or $U$. ruziziensis interfere with $E$. urograndis, reducing the initial growth of the crop; (ii) the interference is more intense when weedy plants grow in short distances from the crop; (iii) the weed $U$. ruziziensis is more competitive than $U$. decumbens with E. urograndis plants; and (iv), in general, plants of E. urograndis clone $\mathrm{C} 219$ accumulate $0.17 \mathrm{~g}$ of above ground dry mass (in leaves + stem) per each centimeter growing far from the $U$. decumbens, and plants of $E$. urograndis clone H15 accumulate $0.38 \mathrm{~g}$ of dry mass (in leaves + stem) per each centimeter growing far from the $U$. ruziziensis, however the eucalypt dry mass is reduced when weed and crop grow in coexistence at least until the distance of $40 \mathrm{~cm}$.

\section{ACKNOWLEDGEMENTS}

The authors thank to the "Conselho Nacional de Desenvolvimento Científico e Tecnológico" (CNPq) of the Federal Governament of Brazil and the "Fundação de Amparo à Pesquisa do Estado de São Paulo" (FAPESP) of the Government of São Paulo State, Brazil, for financial supports.

\section{LITERATURE CITED}

ASSOCIAÇÃO BRASILEIRA DE PRODUTORES DE FLORESTAS PLANTADAS - ABRAF. Anuário estatístico ABRAF 2013: ano base 2012. Brasília: 2013. 148 p.

ANDERSON, W. P. Weed science: principles and applications. 3.ed. New York: West Publishing Company, 1996. 388p.

BARROSO, A. A. M. et al. Effect of the density and distance of slender amaranth and milkweed on the common bean (Phaseolus vulgaris). Planta Daninha, v. 30, n. 1, p. 47-53, 2012. 
BRENDOLAN, R. A.; PELLEGRINI, M. T.; ALVES, P. L. C. A. Effects of mineral nutrition on inter- and intra-specific competition of Eucalyptus grandis and Brachiaria decumbens. 1 - plant growth. Sci. Forest., v. 58, p. 49-57, 2000.

CRUZ, M. B. et al. Guinea Grass and its effects on the initial growth of Eucalyptus x urograndis clones. Ci. Flor., v. 20, p. 391-401, 2010.

DINARDO, W. et al. Effect of Panicum maximum Jacq density on the initial growth of Eucalyptus grandis W. Hill ex Maiden plants. Sci. For., v. 64, n. 1, p. 59-68, 2003.

FOOD AND AGRICULTURE ORGANIZATION OF THE UNITED NATIONS - FAO. World Reference Base for

Soil Resources 2014: international soil classification system for naming soils and creating legends for soil maps. Rome: 2014. $181 \mathrm{p}$.

GARAU, A. M. et al. Weeds in Eucalyptus globulus subsp. maidenii (F. Muell) establishment: effects of competition on sapling growth and survivorship. New For., v. 37, n. 3, p. 251-264, 2009.

MARCOLINI, L. W. et al. Effect of the density and of the distance of Brachiaria decumbens Staff on the initial growth of Coffea arabica L. seedlings. Coffee Sci., v. 4, n. 1, p. 11-15, 2009.

NORRIS, R. F. et al. Spatial arrangement, density, and competition between barnyard grass and tomato: I. Crop growth and yield. Weed Sci., v. 49, n. 1, p. 61-68, 2001a.

NORRIS, R. F. et al. Spatial arrangement, density, and competition between barnyardgrass and tomato: II. Barnyardgrass growth and seed production. Weed Sci., v. 49, n. 1, p. 69-76, 2001b.

PALUDZYSZYN FILHO, E. Sistemas de produção: cultivo de eucalipto. 2010. <http://

sistemasdeproducao.cnptia.embrapa.br/FontesHTML/ Eucalipto/CultivodoEucalipto_2ed/Indicacao.htm>: Accessed: 9 Dec. 2013.

PEREIRA. F. C. M. et al. Response of eucalyptus (Eucalyptus urograndis) plants at different doses of glyphosate. J. Agric. Sci., v. 5, n. 1, p. 66-74, 2010.
PEREIRA, F. C. M.; ALVES, P. L. C. A.; MARTINS, J. V. F. Interference of grasses on the growth of eucalyptus clones. J. Agric. Sci., v. 5, p. 173-180, 2013.

PITELLI, R. A.; MARCHI, S. R. Interferência das plantas invasoras nas áreas de reflorestamento. In: Seminário técnico sobre plantas daninhas e o uso de herbicidas em reflorestamentos. Rio de Janeiro: 1988. p. 44-64.

SILVA, B. P. et al. Interference of slender amaranth, american black nightshade, hairy beggarticks and purple nutsedge on processing tomato. Bragantia, v. 69, n. 2, p. 313-318, 2010.

SILVA, J. R. V.; ALVES, P. L. C. A.; TOLEDO, R. E. B. Weed control strip influences the initial growth of Eucalyptus grandis. Acta Sci. Agron., v. 34, n. 1, p. 29-35, 2012.

SOUZA, L. S.; VELINI, E. D.; MAIOMONIRODELLA, R. C. S. Allelopathic effect of weeds and concentrations of Brachiaria decumbens on the initial development of eucalyptus (Eucalyptus grandis). Planta Daninha, v. 21, n. 3, p.343-354, 2003.

SOUZA, M. C.; ALVES, P. L. C. A.; SALGADO, T. P. Interference of weed community on Eucalyptus grandis second coppice plants. Sci. For., v. 38, n. 1, p. 63-71, 2010.

TOLEDO, R. E. B. et al. Comparação dos custos de quatro métodos de manejo de Brachiaria decumbens em área de implantação de Eucalyptus grandis. R. Árvore, v. 20, n. 3, p. 319-330, 1996.

TOLEDO, R. E. B. et al. Brachiaria decumbens management and effects on the crop development of Eucalyptus grandis.

Sci. For., v. 55, n. 1, p. 129-144, 1999.

TOLEDO, R. E. B. et al. Effects of weed control periods on initial growth and development of eucalypt.

Planta Daninha, v. 18, n. 3, p. 395-404, 2000.

TOLEDO, R. E. B. et al. Effect of Brachiaria decumbens Staf density on the initial growth of Eucalyptus grandis W. Hill ex Maiden plants. Sci. For., v. 60, n. 1, p. 109-117. 2001.

UNITED STATES DEPARTMENT OF AGRICULTURE USDA. Keys to soil taxonomy. 12.ed. Washington: 2014. $360 \mathrm{p}$. 